\title{
PENERAPAN EVALUASI FORMATIF DAN UMPAN BALIK UNTUK MENINGKATKAN KREATIVITAS DAN HASIL BELAJAR SISWA MATA DIKLAT TEKNIK PERMESINAN BUBUT SMK NEGERI 5 PADANG
}

\section{APPLICATION OF FORMATIVE EVALUATION AND FEEDBACK TO IMPROVE THE CRATIVITY AND LEARNING OUTCOMES OF STUDENTS IN THE SUBJECTS OF LATHE MACHINING TECHNIQUE AT SMK NEGERI 5 PADANG}

\author{
Rahmat Rizki $^{(1)}$, Ambiyar ${ }^{(1)}$. \\ Jurusan Teknik Mesin, Fakultas Teknik, Universitas Negeri Padang \\ Kampus Air Tawar, Padang 25131, Indonesia \\ rizkirahmat0212@gmail.com \\ ambiyar@ft.unp.ac.id
}

\begin{abstract}
Abstrak
Berdasarkan survei peneliti, terlihat bahwa dalam proses pembelajaran banyak siswa yang kurang serius, melamun, bermain hand phone, ribut dan keluar masuk saat jam pembelajaran berlangsung. Penelitian ini bertujuan untuk meningkatkan kreativitas dan hasil belajar siswa dengan menerapkan evaluasi formatif dan umpan balik dari evaluasi tersebut. Penelitian ini adalah Penelitian Tindakan Kelas, dimana peneliti bertindak sebagai guru yang melakukan tindakan. Subjek dari penelitian yang dilaksanakan adalah siswa kelas XI Teknik Pemesinan di SMK Negeri 5 Padang berjumlah 16 orang pada mata diklat teknik permesinan bubut. Penelitian ini dilaksanakan selama enam minggu pada bulan September-Oktober 2018. Penelitian ini terdiri dari tiga siklus yang masing-masing terdiri dari dua kali pertemuan. Data dikumpulkan menggunakan lembar observasi untuk melihat perubahan kreativitas belajar siswa setiap siklusnya dan lembaran tes untuk mengukur hasil belajar siswa. Berdasarkan hasil pengamatan, rata-rata kreativitas siklus satu sebesar 56,69\%, siklus dua sebesar $69,97 \%$ dan pada siklus tiga sebesar $81,13 \%$. Selain Kreativitas belajar siswa, hasil belajar juga mengalami peningkatan ketuntasan secara klasikal. Pada siklus satu ketuntasan klasikal adalah $56,25 \%$ dengan 9 siswa tuntas, pada siklus dua adalah 75,00\% dengan 12 siswa yang tuntas, dan pada siklus tiga adalah $87,50 \%$ dengan 14 siswa yang tuntas dari total 16 siswa. Dapat disimpulkan bahwa penerapan evaluasi formatif dan umpan balik dapat meningkatkan kreativitas dan hasil belajar siswa pada mata diklat teknik permesinan bubut kelas XI teknik pemesinan SMK Negeri 5 Padang.
\end{abstract}

Kata kunci: Kreativitas, Hasil Belajar, Evaluasi Formatif, Umpan Balik, Teknik Permesinan Bubut.

\section{Abstract}

Based on the survey of researchers, it can be seen that in the learning process there are many students who are less serious, daydreaming, playing hand phones, making noise and going in and out during the learning hours. This study aims to improve the creativity and learning outcomes of students by applying formative evaluation and feedback from these evaluations. This research is Class Action Research, where the researcher acts as the teacher who takes action. The subjects of the research carried out were students of class XI in Mechanical Engineering at Padang State Vocational High School totaling 16 people in the lathe engineering training program. This research was conducted for six weeks in September-October 2018. The study consisted of three cycles, each of which consisted of two meetings. Data was collected using observation sheets to see changes in student learning creativity each cycle and test sheets to measure student learning outcomes. Based on the results of the observation, the average creativity of the first cycle was $56.69 \%$, the second cycle was $69.97 \%$ and in the third cycle $81.13 \%$. In addition to student learning creativity, learning outcomes also experience an increase in completeness classically. In cycle one classical completeness is $56.25 \%$ with 9 students completing, in cycle two is $75.00 \%$ with 
12 students completing, and in cycle three is $87.50 \%$ with 14 students completing from a total of 16 students. It can be concluded that the application of formative evaluation and feedback can improve the creativity and learning outcomes of students in the Lathe machining engineering class XI machining technique at SMK Negeri 5 Padang.

Keywords: Creativity, Learning Outcomes, Formative Evaluation, Feedback, Lathe Machining Techniques.

\section{Pendahuluan}

Pendidikan diharapkan bisa menimbulkan perubahan pada diri seseorang seperti aspek kognitif,efektif dan psikomotor (Jasman : 2018). Pendidikan berperan penting dalam mempersiapkan sumber daya manusia yang berkualitas. Pendidikan formal yang bertangung jawab pada sumber daya manusia yang terampil dan siap masuk dunia kerja adalah Sekolah Menengah Kejuruan/SMK (Waskito : 2016). Sekolah merupakan lembaga pendidikan tempat proses belajar mengajar berlangsung. Dengan proses inilah tujuan pendidikan akan tercapai dalam bentuk perubahan tingkah laku siswa (Ambiyar : 2016). Terdapat salah satu mata pelajaran produktif yang mendukung tercapainya mutu lulusan yang terampil dan efektif yaitu mata pelajaran Teknik Permesinan Bubut, dimana siswa diharapkan terampil dalam membuat benda kerja pada mesin.

Guru wajib menguasai kemampuan untuk mengelola kelas dan perlengkapan pengajaran hingga aktivitas yang disenangi oleh siswa di dalam kelas (Sumiati : 2013). Seorang guru diharapkan memiliki kemampuan yang baik dalam memilih strategi yang tepat dalam melaksanakan proses pembelajaran di kelasnya, sehingga tujuan pembelajaran sesuai dengan rencana pengajaran dapat tercapai (Primawati : 2017). Kenyataannya masih banyak siswa yang tidak serius dalam proses pembelajaran terlihat dari hasil belajar siswa yang tergolong masih rendah. Faktor yang mempengaruhi hasil belajar digolongkan menjadi dua golongan saja, yaitu faktor intern dan faktor ekstern (Slameto : 2007). Faktor internal dapat mempengaruhi IQ, minat, bakat, persepsi, harapan, ketekunan dan lain-lain. Kemudian faktor eksternal mempengaruhi oleh kurikulum, managemen, ekonomi, sosial, dan para guru yang terdiri dari berbagai faktor seperti media, bahan ajar dan waktu belajar (Suparno :2017). Belajar memuat beberapa unsur, yaitu: (1) penciptaan hubungan; (2) sesuatu hal yang sudah dipahami; dan (3) sesuatu pengetahuan yang baru (Trianto : 2009). Belajar memiliki tiga tujuan, yaitu:

1) Untuk mendapatkan pengetahuan; hal ini ditandai dengan kemampuan berpikir siswa.

2) Penanaman konsep dan keterampilan; penanaman konsep atau merumuskan konsep juga memerlukan keterampilan dengan cara melatih kemempuan melalui bahasa tulis atau lisan.

3) Pembentukan sikap (A.M Sadirman :2012).

Pembelajaran adalah suatu proses terjadinya interaksi guru-siswa melalui kegiatan terpadu dari dua bentuk kegiatan, yakni kegiatan belajar siswa dengan kegiatan mengajar siswa (Nana Sudjana : 2011). Cara mengetahui materi apa saja yang belum dikuasai oleh siswa saat proses pembelajaran, serta kesulitan dan kelemahan apa yang dirasakan oleh siswa, maka evaluasi formatiflah yang tepat diberikan kepada siswa untuk mengukur sampai dimana siswa memahami materi tersebut.

Evaluasi formatif adalah kegiatan yang bertujuan untuk mencari umpan balik, yang selanjutnya hasil penilaian tersebut dapat digunakan untuk memperbaiki proses belajarmengajar yang sedang atau yang sudah dilaksanakan (Ngalim Purwanto : 2012). Jika ditinjau dari fungsinya, evaluasi formatif berfungsi sebagai umpan balik bagi peserta didik, guru maupun program untuk menilai pelaksanaan suatu unit program (Amirono dan Dartono : 2016). Evaluasi formatif bertujuan untuk memperoleh informasi yang diperlukan oleh seorang evaluator tentang siswa guna menentukan tingkat perkembangan siswa dalam satu unit proses belajar mengajar (Sukardi : 2012). Evaluasi formatif dalam penelitian ini diberikan setelah selesai satu bahasan atau di akhir 
pokok bahasan atau biasa disebut ulangan harian, dengan maksud untuk mengetahui ketidakpahaman siswa terhadap materi yang diajarkan oleh guru. Disini guru dapat menilai siswa yang telah paham dan yang belum paham pada pelajaran tersebut.

Penerapan evaluasi formatif ini perlu dilakukan suatu memberikan "umpan balik" supaya siswa juga mengetahui sejauhmana kemampuan mereka dalam menguasai suatu materi. Dengan umpan balik ini juga dapat diketahui kesalahan siswa secara umum, dan mengikutsertakan siswa tersebut untuk memperbaikinya secara langsung. Dengan demikian, umpan balik yang diberikan guru lebih bersifat informatif, dan komunikatif, serta dapat memberikan motivasi kepada siswa untuk memperbaikinya.

Tujuan dari penerapan umpan balik pada evaluasi formatif ini adalah untuk mengantisipasi terjadinya kesalahan dalam proses belajar, karena secara tidak langsung siswa akan memperbaiki pemahamannya tentang suatu materi sedikit demi sedikit. Dan juga diharapkan dapat meningkatkan hasil belajar siswa. Hasil belajar tampak sebagai terjadinya perubahan tingkah laku pada diri siswa, misalnya dari tidak tahu menjadi tahu, dan dari tidak mengerti menjadi mengerti (Oemar Hamalik : 2007). Jadi umpan balik merupakan hal yang perlu diberikan terhadap evaluasi formatif. Umpan balik pada evaluasi formatif ini diharapkan mampu meningkatkan kreativitas belajar siswa. Kreativitas mewujudkan solusi baru dan orisinil terhadap problematika keilmuan, pekerjaan, seni atau sosial, atau menyebutkan sejumlah alternatif baru yang mampu menerobos dan menyelesaikan problematika dengan solusi jitu, baru, dan orisinil (Ibrahim : 2005). Kreativitas yang dimaksud adalah agar siswa memiliki rasa ingin tahu yang tinggi, tertarik pada tugas yang diberikan guru, dan memiliki motivasi belajar yang tinggi. ada tiga kondisi dari pribadi kreatif:

1) Keterbukaan terhadap pengalaman.

2) Kemampuan untuk menilai situasi sesuai dengan patokan pribadi seseorang (internal locus of evaluation).

3) Kemampuan untuk bereksperimen, untuk bermain dengan konsep-konsep (Utami Munandar : 2009).
Umpan balik pada evaluasi formatif ini akan dijadikan titik tolak untuk memperbaiki hasil belajar siswa yang kurang maksimal.

\section{Metode Penelitian}

Jenis penelitian yang penulis lakukan adalah penelitian tindakan kelas (PTK) atau dikenal sebagai classroom action research (CAR) yang pelaksanaannya dilakukan degan cara berkolaborasi dengan kolaborator. PTK dilakukan oleh guru di kelasnya sendiri dengan cara (1) merencanakan; (2) melaksanakan; (3) merefleksikan tindakan secara kolaboratif dan partisipatif dengan tujuan memperbaiki kinerja, sehingga hasil belajar siswa dapat meningkat (Wijaya Kusumah : 2012). Secara etimologis,ada tiga istilah yang berhubungan dengan penelitian tindakan kelas (PTK), yakni penelitian, tindakan dan kelas (Wina Sanjaya : 2011).

Metode PTK ini digunakan untuk memecahkan permasalahan yang timbul di dalam kelas dan untuk meningkatkan kualitas proses dan hasil pembelajaran di kelas karena permasalahan yang ditemukan dan dihadapi guru diperoleh dari kegiatan belajar dan pembelajaran di kelas.

Data pada penelitian ini dikumpulkan dari dua jenis data yakni data kuantitatif adalah data yang diambil dari nilai tes hasil belajar siswa dan data kualitatif diambil dari pengamatan terhadap kegiatan siswa pada saat penelitian dilakukan. Sumber data terdiri dari: (1) sumber data primer, yaitu nilai tes pada setiap akhir siklus; (2) sumber data sekunder, yaitu data hasil pengamatan yang dilakukan oleh observer yang dalam penelitian ini adalah peneliti sendiri dibantu dengan seorang kolaborator yang merupakan teman sejawat peneliti.

Instrumen pengumpulan data ialah alat yang digunakan untuk pengumpulan data agar kegiatan tersebut menjadi mudah (Bulkia Rahim : 2018). Terdapat beberapa instrumen yang digunakan untuk mengumpulkan data pada penelitian yang dilakukan, yaitu:

\section{Lembar Pengamatan}

Lembaran pengamatan berperan sebagai alat pengumpul data kualitatif yang digunakan untuk mengumpulkan data tentang kreativitas siswa dalam proses pembelajaran. Untuk melihat persentase peningkatan kreativitas 
siswa pada setiap siklusnya maka lembar pengamatan ini akan diolah secara kuantitatif agar memudahkan dalam mengolah data hasil pengamatan untuk melihat besarnya persentase yang didapatkan.

\section{Lembaran Tes}

Tes adalah serangkaian pertanyaan atau latihan atau alat lain yang digunakan untuk mengukur keterampilan, pengetahuan, kecerdasan, kemampuan, atau bakat yang dimiliki oleh seseorang atau kelompok (Ambiyar : 2012). Lembaran tes berperan sebagai alat pengumpul data kuantitatif yang berupa tes tertulis berbentuk tes objektif.Tes dibuat berdasarkan kisi-kisi pada indikator yang terdapat dalam silabus.Lembaran tes digunakan untuk mengumpulkan data hasil belajar. Sebelum dilakukannya pengambilan data menggunakan lembaran tes ini, maka terlebih dahulu terhadap soal-soal tes yang akan digunakan dilakukan uji coba.

Teknik analisis data yang digunakan adalah sebagai berikut:

\section{Kreativitas}

Data isian lembar pengamatan kreativitas belajar siswa akan dianalisis dengan cara kuantitatif dalam bentuk persentase. Untuk melihat persentase kreativitas siswa pertahapnya digunakan ketentuan sebagai berikut:

$\mathrm{P}=\frac{\sum X}{\sum Y} x 100 \%$

Dengan keterangan:

$\mathrm{P}$ : Persentase kreativitas yang diamati setiap pertemuan

$\sum \mathrm{X}:$ Jumlah skor kreativitas siswa

$\sum \mathrm{Y}$ : Jumlah skor maksimal kreativitas

Selanjutnya dalam keterangan persentase yang diperoleh sebagai interpretasi kreativitas belajar penilaian akan berpedoman pada tabel berikut:

Tabel 1. Klasifikasi Penilaian Kreativitas Siswa

\begin{tabular}{ccc}
\hline No & Interval & Kategori \\
\hline 1 & $\geq 75,1 \%$ & Kreatif \\
2 & $60 \%-75 \%$ & Cukup Kreatif \\
3 & $\leq 59,9 \%$ & Kurang Kreatif \\
\hline
\end{tabular}

\section{Hasil Belajar}

Penilaian didapatkan dari tes formatif diadakan setelah selesai satu siklus dengan KKM yang ditetapkan 80. Menurut Depdiknas (2004) persentase penilaian dilakukan menggunakan rumus:

$\mathrm{NI}=\frac{\mathrm{T}}{\mathrm{SM}} \times 100 \%$

Dengan keterangan:

NI : ketuntasan belajar secara individu

$\mathrm{T}$ : Skor yang diperoleh siswa

SM : Skor maksimum dari tes

Ketuntasan belajar individu ini mengacu kepada ketentuan yang telah ditetapkan dalam kurikulum SMK Negeri 5 Padang yaitu sebesar 80 .

$\mathrm{NT}=\frac{\mathrm{ST}}{\mathrm{n}} \times 100 \%$

Dengan keterangan:

NT: Ketuntasan belajar secara klasikal

ST : Jumlah siswa yang tuntas belajar

$\mathrm{N}$ : Jumlah seluruh siswa dalam satu kelas

Ketuntasan klasikal tercapai apabila nilai ketuntasan klasikal kelas telah mencapai persentase nilai $80 \%$ maka siswa di kelas tersebut dinyatakan telah tuntas sehingga penelitian akan dihentikan.

\section{Hasil dan Pembahasan}

\section{A. Tahap Perencanaan}

Langkah awal yang harus dipersiapkan adalah RPP dan bahan ajar tentang memahami mesin bubut untuk jenis pekerjaan tertentu yang diisyaratkan. Selanjutnya menyiapkan lembar observasi dan lembar tes berupa pilihan ganda. Lembar observasi kreativitas ini dijadikan sebagai informasi tentang tingkat kreativitas siswa mulai dari awal hingga akhir pembelajaran berlangsung. Sedangkan lembaran tes berfungsi untuk mengetahui hasil belajar siswa. Diluar juga alat dokumentasi berupa hand phone yang digunakan sebagai alat dokumentasi selama proses pembelajaran dengan penerapan Evaluasi Formatif dan Umpan Balik. Pelaksanaan tindakan kelas dilakukan sebanyak 3 siklus dimana satu siklus terdapat 2 kali pertemuan. 


\section{B. Pengamatan}

Waktu melaksanakan penelitian ini, peneliti dibantu teman sejawat dalam kegiatan ini selaku observer untuk mengamati kreativitas siswa selama proses pembelajaran berlangsung dengan penerapan evaluasi formatif dan umpan balik. Observer mengamati proses pembelajaran dari belakang kelas setiap pertemuan dan observer sesekali juga berjalan di dalam kelas untuk mengamati jalannya proses diskusi untuk mengamati kreativitas siswa secara dekat.. Hasil kreativitas belajar dan hasil tes siswa didapatkan hasil sebagai berikut:

\section{Kreativitas}

Berikut ini adalah hasil pengamatan kreativitas belajar siswa yang diamati pada siklus I sebanyak 2 kali pertemuan dan hasilnya diketahui bahwa sebanyak 9 siswa kreativitas dalam melaksanakan pembelajaran tergolong kurang kreatif, sebanyak 7 siswa tergolong cukup kreatif, dan belum ada siswa yang tergolong kreatif. Berdasarkan hasil perhitungan kreativitas pada siklus I ini, didapatkan rata-rata kreativitas adalah 56,69\% yang artinya jauh dari indikator kreativitas yaitu sebesar $80 \%$ dengan keterangan kurang kreatif.

Perhitungan pada siklus II didapatkan hasil sebanyak 6 siswa tergolong kreatif dan sebanyak 10 siswa tergolong cukup kreatif. Berdasarkan hasil perhitungan kretivitas pada siklus 2 ini, didapatkan rata-rata kreativitas adalah $69,978 \%$ yang artinya masih belum memenuhi indikator kreativitas yaitu sebesar $80 \%$ dengan keterangan cukup kreatif, tetapi sudah mulai meningkat dibandingkan pada siklus I.

Indikator kreativitas yang ditetapkan yaitu sebesar 80 dan belum tercapai pada siklus II, maka dilanjutkan pada siklus III dan didapatkan hasil pengamatan bahwa sebanyak 13 siswa kreativitas dalam melaksanakan pembelajaran tergolong kreatif dan sebanyak 3 siswa tergolong cukup kreatif. Berdasarkan hasil perhitungan kreativitas pada siklus III ini, didapatkan rata-rata kreativitas adalah $81,138 \%$ yang artinya sudah memenuhi indikator kreativitas yaitu sebesar $80 \%$ dengan keterangan kreatif.

2. Hasil Belajar
Hasil belajar dapat diukur dengan cara mengadakan tes objektif pada akhir siklus. Didapatkan hasil bahwa sebanyak 9 siswa telah memenuhi nilai KKM yang ditentukan pada mata diklat teknik permesinan bubut yaitu ini sebesar 80 dan 7 orang siswa belum memenuhi KKM. Berdasarkan hasil perhitungan hasil belajar, didapatkan nilai ketuntasan klasikal sebesar 56,25\% yang artinya belum memenuhi indikator ketuntasan klasikal yaitu sebesar $80 \%$.

Dilanjutkan pada siklus II dan didapatkan hasil sebanyak 4 orang belum memenuhi KKM sebesar 80. Jadi, siswa yang tuntas sebanyak 12 orang dengan persentase ketuntasan klasikal sebesar $75 \%$ dan siswa yang belum mencapai ketuntasan sebanyak 4 orang dengan persentase $25 \%$. Ketuntasan klasikal siswa sebesar $75 \%$ menunjukkan bahwa indikator keberhasilan tindakan pada siklus II belum tercapai dan dilanjutkan pada siklus III.

Siklus III didapatkan hasil sebanyak 2 siswa belum memenuhi KKM sebesar 80. Jadi, siswa yang tuntas sebanyak 14 orang dengan persentase ketuntasan klasikal sebesar 87,5\% dan siswa yang belum mencapai ketuntasan sebanyak 2 orang dengan persentase $12,5 \%$. Ketuntasan klasikal siswa sebesar 87,5\% menunjukkan bahwa indikator keberhasilan tindakan siklus III telah tercapai.

\section{Refleksi (Reflecting)}

\section{Evaluasi Pelaksanaan Tindakan}

Kelemahan yang ditemukan pada siklus I terdapat pada pertemuan 1 dimana siswa terlalu heboh ketika diinstruksikan duduk pada masing-masing kelompok dan memakan waktu beberapa menit agar semua siswa bisa tenang dan duduk dengan kelompoknya masing-masing.Hal ini disebabkan karena masih banyak siswa yang bercanda gurau saat diintruksikan untuk duduk pada kelompoknya walaupun kelompok sudah dibagi oleh guru mata pelajaran yang bersangkutan yaitu kelompok untuk membuat benda kerja. Presentasi yang dilaksanakan pada siklus I menyediakan waktu yang cukup singkat bagi masing-masing kelompok untuk dilakukannya tanya jawab yaitu hanya selama 5 menit untuk masing-masing kelompok dengan total 5 kelompok. 


\section{Tindakan Perbaikan}

Guru menyampaikan mengenai aspek pengamatan kreativitas, dimana masih banyak siswa yang belum menunjukkan sifat kreatif dalam proses belajar mengajar dan guru membacakan satu per satu dari aspek tersebut dan persentase dari aspek tersebut agar siswa tahu dimana kelemahan mereka, dan supaya mereka merubah tingkah laku mereka dari yang tidak kreatif menjadi pribadi yang kreatif.

Guru juga memberikan umpan balik dari evaluasi formatif atau biasa disebut dengan ulangan harian siswa, agar seluruh siswa mengetahui dimana mereka menjawab dengan salah, sehingga mereka tahu jawaban yang benar. Dan guru menyampaikan kepada siswa agar mereka lebih serius dan fokus dalam proses pembelajaran dan juga belajar tidak hanya di sekolah tetapi mereka harus juga belajar di rumah, sehingga bisa meningkatkan kreativias dan hasil belajar siswa tersebut. Karena individu yang kreatif tidak pernah puas dengan hasil belajar yang rendah dan mereka ingin memiliki nilai yang tinggi.

\section{Pembahasan}

1. Peningkatan Kreativitas Siswa pada Mata Diklat Teknik Permesinan Bubut dengan Penerapan Evaluasi Formatif dan Umpan Balik.

Pelaksanaan pembelajaran siklus I didapatkan rata-rata kreativitas siswa dalam kategori kurang kreatif yang kemudian meningkat pada siklus II menjadi kategori cukup kreatif dan dilanjutkan pada siklus III menjadi kategori kreatif. Dari siklus II ke siklus III, siswa terlihat lebih kreatif dalam proses diskusi dan berupaya mencari jawaban dari pertanyaan yang diberikan. Bila siswa tidak mengerti dengan materi, siswa mulai berani bertanya pada guru dan menanggapi pertanyaan yang ada dengan cara yang semakin baik serta membaca handout dengan baik untuk menemukan jawaban dari pertanyaan. Terlihat siswa mulai dapat bekerjasama dalam proses diskusi dan berani tampil mempresentasikan hasil diskusinya.

Waktu proses pembelajaran seorang guru harus tahu evaluasi yang diberikan setelah melihat hasil pembelajaran agar bisa meningkatkan hasil belajar siswa. Evaluasi yang digunakan oleh seorang guru akan berpengaruh terhadap kualitas dan hasil belajar siswa. Dan juga guru harus tahu cara meningkatkan hasil belajar siswa. Setelah dilakukan penelitian diketahui kreativitas dan hasil belajar siswa dapat meningkat melalui penerapan evaluasi formatif dan umpan balik. Karena melalui penerapan evaluasi formatif guru dapat menetahui dimana siswa tidak mengerti suatu materi pembelajaran dan melalui umpan balik siswa juga mengetahui dimana siswa tersebut salah dalam menjawab soal mengenai materi yang diajarkan.Oleh karena itu pembelajaran dapat berjalan dengan lancar dan guru membahas kembali bagian dari materi yang belum dukuasai oleh siswa sehingga hasil belajar siswa dapat meningkat.

2. Peningkatan Hasil Belajar Siswa pada Mata Diklat Teknik Permesinan Bubut dengan Penerapan Evaluasi Formatif dan Umpan Balik.

Deketahui terjadi peningkatan jumlah siswa yang memperoleh nilai mencapai KKM dengan menggunakan evaluasi formatif dan umpan balik. Pada pembelajaran siklus I, dari total 16 siswa sebanyak 9 orang siswa memperoleh nilai sesuai KKM dengan persentase ketuntasan klasikal sebesar $56,25 \%$ dan 7 orang $(43,75 \%)$ yang belum memperoleh nilai mencapai 80. Pada siklus II, dari total 16 siswa jumlah siswa yang memperoleh nilai 80 bertambah menjadi 12 siswa dengan ketuntasan klasikal 75\% dan 4 orang $(25 \%)$ belum memperoleh nilai mencapai 80. Dan pada siklus III, dari total 16 siswa jumlah siswa yang memperoleh nilai 80 bertambah menjadi 14 siswa dengan ketuntasan klasikal $87,5 \%$ dan 2 siswa $(12,5 \%)$ belum memperoleh nilai 80 .

\section{Kesimpulan}

Berdasarkan hasil analisis data yang didapatkan saat penelitian berlangsung dapat ditarik beberapa kesimpulan sebagai berikut:

1. Penerapan evaluasi formatif dan umpan balik dapat meningkatkan kreativitas dan hasil belajar siswa. 
2. Peningkatan kreativitas ini dibuktikan dari peningkatan kreativitas siswa dari siklus I sebesar $56,69 \%$ dengan kategori kurang kreatif menjadi $69,97 \%$ pada siklus II dengan kategori cukup kratif dan menjadi $81,13 \%$ pada siklus III.

3. Peningkatan hasil belajar ini dibuktikan dari peningkatan ketuntasan klasikal yang sebelumnya pada siklus I sebesar 56,25\% dengan 9 siswa yang tuntas meningkat dengan baik pada siklus II menjadi $75,00 \%$ dengan 12 siswa dan pada siklus III menjadi $87,5 \%$ dengan 14 siswa yang tuntas dari total 16 siswa.

\section{Referensi}

Ambiyar. 2012. Pengukuran dan Tes dalam Pendidikan. Padang : UNP Press

Ambiyar dkk.(2016). Penerapan Model Pembelajaran Praktek Terbimbing Mata Diklat Las Busur Manual Untuk Meningkatkan Aktivitas dan Hasil Belajar Praktek Siswa Kelas XI Jurusan Teknik Mesin SMK Muhammadiyah 1 Padang.

Amirono, dan Dartono. 2016. Evaluasi dan Penilaian Pembelajaran Kurikulum 2013. Yogyakarta: Penerbit Gava Media.

A.M. Sardiman. 2012. Interaksi dan Motivasi Belajar Mengajar. Jakarta: PT. Raja Grafindo Persada.

Bulkia Rahim dkk. (2018). Validitas Modul Pembelajaran Model Kooperatif Tipe Jigsaw Pada Mata Kuliah Teori Teknik Fabrikasi Vol 1, No. 2.

Ibrahim Al Maghazi. 2005. Menumbuhkan Kreativitas Anak. Jakarta: Cendekia

Jasman dkk .(2018). Persepsi Siswa Terhadap Keterampilan Dasar Mengajar Mahasiswa Program Pengalaman Lapangan Kependidikan (PPLK) pada Mata Diklat Gambar Teknik di Smk Negeri 5 Padang.
Nana Sudjana, (2011). Dasar-dasar Proses Belajar Mengajar. Bandung: Sinar Baru Algesindo.

Ngalim Purwanto, 2012. Prinsip-Prinsip dan Teknik Evaluasi Pembelajaran. Bandung: PT Rosdakarya.

Oemar Hamalik, 2004. Proses Belajar Mengajar. Jakarta: Bumi Aksara.

Primawati, dkk. Peningkatan Aktivitas dan Hasil Belajar Siswa Menggunakan Metode Talking Stick. Padang. Jurnal Invotek Vol. 17 No. 1 April 2017.

Sukardi. 2012. Evaluasi Pendidikan : Prinsip dan Operasionalnya. Jakarta: Bumi Aksara.

Sumiati dan Asra. 2013. Metode Pembelajaran. Bandung: Wacana Prima.

Slameto (2007).Belajar dan faktor-faktor yang mempengaruhinya. Jakarta: PT Rineka Cipta.

Suparno.(2017). Respon Mahasiswa Pembelajaran Kooperatif Jigsaw dan Modul Pembelajaran pada Mata Kuliah Media Pendidikan.

Trianto. 2009. Mendesain Model Pembelajaran Inovatif-Progresif. Jakarta: Kencana

Utami Munandar, (2009). Pengembangkan Kreativitas dan Bakat. Jakarta: PT. Gramedia

Waskito dkk. (2016). Kontribusi Minat Kerja dan Penguasaan Mata Pelajaran Produktif Terhadap Keberhasilan Praktek Kerja Industri Siswa Kelas XII Program Teknik Pemesinan di SMK Negeri 2 Solok

Wijaya Kusumah. 2012. Penelitian Tindakan Kelas. Jakarta: PT. Indeks

Wina Sanjaya, (2011). Penelitian Tindakan Kelas. Jakarta: Kencana 